\title{
Human Resource Outsourcing: A Study on Telecommunication Sector in Bangladesh
}

\author{
Khaled Mahmud ${ }^{1}$, Mohammed Msum Billah ${ }^{2} \&$ Syed Mustafizur Rahman Chowdhury ${ }^{2}$ \\ ${ }^{1}$ Institution of Business Administration, University of Dhaka, Bangladesh \\ ${ }^{2}$ Department of Business Administration, Northern University Bangladesh, Bangladesh \\ Correspondence: Khaled Mahmud, Lecturer, Institution of Business Administration, University of Dhaka, Dhaka \\ 1000, Bangladesh. Tel: 88-017-1253-6013. E-mail: khaled@iba-du.edu
}

Received: February 5, 2012 Accepted: March 19, 2012 Online Published: May 16, 2012

doi:10.5539/ijbm.v7n10p74

URL: http://dx.doi.org/ijbm.v7n10p74

\begin{abstract}
The objective of the study is to represent the current state of outsourcing of Human Resource functions at telecommunication sector in Bangladesh. Specifically, the study addresses the issues of when and under what circumstances does HR outsourcing contribute value to the companies by attempting to identify environmental and organizational characteristics that affect HR department performance and how HR outsourcing mediates that relationship in service organization like telecommunication sector. It tries to find out the relationship between outsourcing and numbers of employees within the organization and also shows the relationship between outsourcing and number of employees in HR department. Most of the companies are highly interested to outsource recruitment and selection functions whereas temporary staffing is in the least position for outsourcing. Companies show maximum satisfaction to improve in service quality due to outsourcing HR functions but in some extent it reduces the effectiveness of human capital management.
\end{abstract}

Keywords: human resource outsourcing, telecommunication, business process outsourcing, temporary staffing, human capital management

\section{Introduction}

Human Resource Outsourcing is the process of subcontracting human resources functions to a third-party supplier. Outsourcing can be seen as a process in which a company delegates some of its in-house operations to a third party through which the company acquires services from another while maintaining ownership and ultimate responsibility for the processes. The primary motive for outsourcing includes enabling the company to invest more time, money and human resources into core activities and building strategies to facilitate company growth. In todays increasingly competitive and rapidly changing global market a company has little choice but to concentrate on improving productivity while cutting down costs. As a result, a variety of different processes that take up precious time and resources are being outsourced. Business Process Outsourcing (BPO) companies are often considered to provide more flexible, faster, cheaper and effective services.

Human resource functions outsourcing comes a long way. The history depicts that through specialization contracting began to be more accepted, especially in the service industry. This was the beginning of the first wave of outsourcing in the time of the industrial uprising approaching the growth of services such as insurance services, architecture and engineering services. At this time the companies doing the outsourced work, were mostly located in the same country, often in the city, just like the customers.

Companies those are multinationals, or from western countries and BPO units in countries such as Malaysia, China, Russia and India even are looking forward to outsource. The operations or processes being outsourced vary from manufacturing to customer service to software development and much more. Services such as, contract programming, bureau services, and project management have been outsourced for a long time. Business process outsourcing refers to such greater level of handing over ownership and control as its HR related activities to a single or combination of service provides located, at times, even beyond the bounderies of its own country such as Philippines, China, India and so on.

Human Resource Outsourcing can help cutting costs, concentrating on core business and most importantly in ensuring employee satisfaction. Companies can save huge amounts of money by Human Resource Outsourcing 
and be free of complications that are otherwise involved in maintaining an internal HR department. Companies can concentrate on their core competencies which will save them their valuable time and resources. Some industry experts believe that Human Resource Outsourcing is the future, making the next generation of in-house professionals simply integrators of the company's outsourced services.

The main goal of the study is to reveal the existing practices of outsourcing of human resources functions in telecommunication sector in Bangladesh. At the same time the study was conducted to find out the causes of out sourcing and the satisfaction level of those who are outsourcing human resources functions.

\section{Literature Review}

Although there are lots of theoretical and empirical articles and on outsourcing organizational function such as information system and accounting, the academic literature on outsourcing the HR functions is almost non-existing. In the topic of human resource outsourcing, the top and most important argument that comes in discussion is the cost benefit analysis for firing out services which were performed internally (Anderson et al, 1986; Greer et al, 1999; Gupta et al, 1992; Kakabadse et al, 2002; Lever, 1997), and Vining \& Globerman (1999) note that empirical data from government agencies outsourcing to private suppliers generated savings in the range of 20-30\% in production costs. Some of the studies from these authors concern that there should be other factors except cost which should be considered at the time of taking outsourcing decision. Other factors include vendor customer satisfaction, employee satisfaction and expertise (Barthelemy, 2003) and loss of strategic advantage. Adler (2003) notes that a review by the Granter group listed six factors that are important in outsourcing decisions: dependency risk, spillover risk, trust, relative proficiency, strategic capabilities, and flexibility. The first four of these factors are short term factors, whereas the last two are considered more long term or strategic. However, no clear formula exists that identifies when outsourcing is most efficient and effective.

The question arises that what are the situations where the outsourcing is most desirable and under what circumstances an organization should outsource to increase effective performance by its human resources. In other words are there internal and external forces that their conductive to HR outsourcing? If these forces can be acknowledged that they provide some signs relating to the appropriate action to take when outsourcing is being considered. This is especially important science $67 \%$ of HR departments outsourced one or more function in 2004 (Bureau of National Affair, 2004). We especially address the issue of when and under what circumstance does HR outsourcing contribute value to the firm by attempting to identify environmental and organizational characteristics that effect HR performance and how HR outsourcing mediates that relationship.

Another issue that concerns the current outsourcing research is the absence of studies looking of the HR functions in organization. Klaas (2003) develop a framework that helps analyze HR outsourcing factors in small and medium sized enterprise (SMEs) by explicating on the relationship between SMEs and the professional employer organization and Gainey and klaas (2003) analyze HR function specifically in the context of training and development these studies are expectation rather than the rule. This fact is surprising given that many HR function such as pay role, benefits, training, and recruiting are often outsourced by organization(Gilley et al, 2004).

The SHRM Human Resource outsourcing Survey Report released in june 2004 found that HR function that are entirely background checking, employee assistance/counseling and Flexible Spending include administration. The outsourced functions include management of health care benefit, pension benefit administration and payroll. Despite these increment in HR outsourcing activities to date the empirical articles on outsourcing HR function focus on the impact of organizational characteristics (Klaas, 2003), the role, the transaction costs (Gainey et al, 2003; Klaas, 2003; Klaas et al, 1999), the relationship between HR departments, size and outsourcing activity (Pommerenke et al, 1996) and the rational and consequence of HR outsourcing, and the time of outsourcing (Greer et al, 1999). The question concerning the appropriate time to outsource HR practices based on the internal and external forces driving the firm to consider outsourcing however is not directly addressed, although Klaas, McClendon \& Gainey (1999) come close in their analysis of moderate variables in the relationship between amount of HR outsourcing and perceived benefits from outsourcing. A separate article by Klaas, McClendon \& Gainey (2001) also discussed on few organizational characteristics that lead firms to outsource the HR activities but does not consider HR performance as a dependent variable. As such it is necessary to address the question of when to outsource the HR function by looking into the theoretical issue of outsourcing in the literature representing disciplines other that HR to from a basis for HR outsourcing. However a brief discussion of definitions and HR activities is presented first.

Gilley Greer and Rasheed (2004) discussed a strategic typology of HR activities develop by Greer (2001) in 
which HR activities are classified as having either high or low strategic value and as being either transaction or relationship oriented in nature. Their resulting typology shows the quadrant containing relation oriented activities related to training and performance evaluation. When the HR activities listed by Gilley, et al. (2004) are located in the HR value chain, it becomes certain that portions of each major HR functions are potential candidates for outsourcing. However, three functions in particular, training, performance planning and evaluation and compensation deal specifically with an organization's current relationship with it employees.

A notable recent trend has been the increased use of contingent and temporary workers, or the outright outsourcing of Human Resource functions (Harkins et al, 1995). A 1996 survey by the American management Association found that $77 \%$ of their respondents outsourced some functions, up from $60 \%$ in 1994 . Other HR departments, under budgetary and managerial pressure, are simply eliminating certain services previously provided by HR staff.

A number of competitive forces have been identified as drivers of the trend to outsourcing (Greer et al, 1999). These include: downsizing of internal staff, rapid growth or decline, increased competition, and restructuring. The push to reduce costs drives many outsourcing decisions. A number of other reasons for outsourcing have been identified as well. (Cook, 1999; Greaver, 1999; Greer et al., 1999; Milgate, 2001).

Lever (1997) cautions that "the old HR staffing rule of one HR staff member for every 100 employees is not as meaningful today as a measure of HR efficiency or effectiveness as in the past". Annualized HRO spending has experienced a significant and consistent growth over times. Whereas HRO spending represented US $\$ 75$ million in 1998, it's skyrocketing at an increasing rate to well over US \$ 1500 million in the year 2004(nearly $80 \%$ increase per year). Towards the end of modern day the trend of outsourcing has moved into the world of data transcription, information technology and call center operations. Studies on the history of outsourcing conclude that outsourcing is clearly not just about payrolls and call centers. This can be seen by simply looking into the medicine cabinet. It is very likely that the R\&D of the daily medicine was outsourced to companies in India. The insurance company which covers the costs of the medications may have their claim processing to offshore transcription providers. And the medical clinic may easily be outsourcing the administration of your confidential medical records to Russia, the Philippines of India.

Outsourcing human resource activities in our country is nothing new at all. Government has been outsourcing, specially, in construction sector since long. Farmers in villages do outsource during the time of harvesting crop. In domestic level, people outsource carpenters, masons and other kind of activities. And so forth. Recently, private sector employers are more interested in outsourcing different activities apart from their line of business. RMG manufacturers, construction firms, Banks, telecom operators are frequently outsourcing their different need of human resource.

But all these, apart from government jobs, have been being operated in ad-hock basis. There has never been any organization to give the Human Resource Management service for other organizations until recently. Still the number of such HR service providers is nothing other than one. Our research has determined only Monowara associates. Apart from this BDJobs.com and similar online based organizations are coming up with recruitment and training solutions. All other services are somehow collected in personal contact through local contractors. These contractors operate in mostly in so unorganized way that for organizations searching for such services find it difficult to contact them. And for the same cause we had a difficulty in finding any such information.

\section{Objectives of the Study}

The main purpose of the study is to know about the practices of outsourcing of human resources functions in telecommunication sector in Bangladesh.

Specific objectives are:

- To find out the relationship between existence of HR department and number of employees in telecommunication sector.

- To find out the relationship between outsourcing and number of total employees in telecommunication sector.

- To find out the relationship between outsourcing and number of employees in HR department in telecommunication sector.

- To find out the relative importance of different HR functions in telecommunication sector.

- To find out the causes of outsourcing in telecommunication sector.

- To find out the causes of not outsourcing in telecommunication sector. 
- To find out the satisfaction level of different companies having outsourcing some human resources functions.

\section{Methodology}

With a view to conducting a research study, what is necessary is to design the research framework and select the appropriate research methodology. Given the nature of the present study, it was required to collect data both from the primary and the secondary sources.

Secondary data were collected by consulting various documents, such as, Office-Order; financial manuals, accounts manual, Annual Reports, Employee profile, Employee data base prepared by Human Resource Department, and relevant Journals.

The judgmental sampling procedure was used to select the sample units from Human resources division officers of different companies of telecommunication sector who were willing to respond to the questionnaire. Total numbers of respondents were fifty, selected from four companies named Robi, Grameenphone, Banglalink and Airtel.

We have prepared a questionnaire and collected data from the companies. The questionnaire consists of eleven questions. Based on the responses to this questionnaire we have prepared the survey result.

The jargons that have been used in the questionnaire are all related to standard HRM practices. This may seem not so easy for ordinary people to understand. However our target audience is the HR professionals, which ultimately justify such choice.

a) Questions 01 through 03 are to know about the type of business the organization is in, and its management. These questions serve the purpose of finding any intrinsic correlation of any kind of human resource outsourcing and the management practice and/ or type of business.

b) Question 04 is to find the total number of employees in the organization, while questions 05 and 06 deal with findings whether the organization has any HR department. If yes, then how many employees are there in the department? The answers from these three questions will give us an understanding of correlation of having HRD with the number of total employees. When we add the answer from question 07, which answers whether the organization outsourcers any HR activities, will widen our understanding of the relations among these factors.

c) The first part of question 08 has been designed to find the effect, in ordinal scale, of nine different HR activities on overall performance of the organization. Collected data has been converted into interval scale in analysing and further comparison. This data would later be used in collaboration of others found in questions afterwards. The second part simply is to know whether the organization outsource those functions or not.

d) Question 09 inquires the reason(s) for outsourcing, if they do or why would they consider outsourcing, if they don't do that already.

e) Question 10 is the continuation of question 08. If the answer of the second part is no, then this question inquires the reasons in ordinal scale, which later would be converted into interval scale assigning certain point in each order.

f) In the last question (number 11), we will have a picture of the level of satisfaction connected to different expectations of the organizations who are currently outsourcing HR functions. This is actually a vital feedback for the HRM outsourcing firm, providing the service.

\section{Findings of the Study}

\subsection{Relationship between Existence of HR Department and Number of Employee}

Regardless of the number of employee, all the organizations we have surveyed have HR departments. The range of number of employee was 800 to 5000 with an average of 2100 people. The number of employees in HR department varies from 14 to 50 people with an average of 23 people. Total employees per person in HR department vary from 53 to 106 .

\subsection{Relationship between Outsourcing and Number of Total Employee}

It appears, as the number of the people in an organization increases, the necessity of outsourcing emerges. To find whether there is any relationship between outsourcing and total number of employees in an organization, CHI SQUARE test was done.

Result of the analysis:

Table 1, 2 and 3 show the result of the analysis. The analysis shows that at 0.5 level of significance and 2 degree 
of freedom the calculated value of CHI square is 1.8333 which is less than the table value 5.99 . So, at 5 percent level of significance, we can conclude that there is no significant relationship between outsourcing HR functions and total number of employees.

Table 1. Observed Frequency (Relationship between outsourcing and number of total employee)

\begin{tabular}{cccc}
\hline Total Employee & Yes & No & \\
\hline More than 2000 & 1 & 0 & 1 \\
1000 to 2000 & 1 & 1 & 2 \\
Below 1000 & 0 & 1 & 1 \\
& 2 & 2 & 4 \\
\hline
\end{tabular}

Table 2. Expected Frequency (Relationship between outsourcing and number of total employee)

\begin{tabular}{lccc}
\hline Employee & Yes & No & \\
\hline More than 2000 & 0.666667 & 0.666667 & 1.333333 \\
1000 to 2000 & 1.333333 & 1.333333 & 2.666667 \\
Below 1000 & 0.666667 & 0.666667 & 1.333333 \\
& 2.666667 & 2.666667 & 5.333333 \\
\hline
\end{tabular}

Table 3. Chi-square test result (Relationship between outsourcing and number of total employee)

\begin{tabular}{ccc}
\hline $\begin{array}{c}\text { Yes } \\
(\mathrm{O}-\mathrm{E})^{2} / \mathrm{E}\end{array}$ & No \\
$(\mathrm{O}-\mathrm{E})^{2} / \mathrm{E}$ & \\
\hline 0.166667 & 0.666667 & \\
0.083333 & 0.083333 & \\
0.666667 & 0.166667 & ACCEPT \\
\hline \multicolumn{4}{c}{$\sum(\mathrm{O}-\mathrm{E})^{2} / \mathrm{E}=1.833333$} & \\
\hline
\end{tabular}

\subsection{Relationship between Outsourcing and Number of Employees in HR Department}

Apparently, many people are under the impression that there is a negative correlation between the number of employees in the HR department and outsourcing HR functions. To find the relationship between number of people in HR department and outsourcing, again, CHI Square test was done.

Result of the analysis:

Table 4, 5 and 6 show the result of the analysis. The result shows that at $5 \%$ level of significance and 2 degree of freedom the calculated value of chi square is 1.8333 which is less than the table value of 5.99. So, we can conclude that there is no significant relationship between outsourcing and number of employees in HR department.

Table 4. Observed frequency (Relationship between outsourcing and number of employees in HR department)

\begin{tabular}{llll}
\hline HR Employee & Yes & No & \\
\hline More than 30 & 1 & 0 & 1 \\
15 to 30 & 1 & 1 & 2 \\
Less than 15 & 1 & 0 & 1 \\
& 3 & 1 & 4 \\
\hline
\end{tabular}

Table 5. Expected frequency (Relationship between outsourcing and number of employees in HR department)

\begin{tabular}{llll}
\hline Employee & Yes & No & \\
\hline More than 30 & 1 & 0.333333 & 1.333333 \\
15 to 30 & 2 & 0.666667 & 2.666667 \\
Less than 15 & 1 & 0.333333 & 1.333333 \\
& 4 & 1.333333 & 5.333333 \\
\hline
\end{tabular}


Table 6. Chi-square test result (Relationship between outsourcing and number of employees in HR department)

\begin{tabular}{ccc}
\hline $\begin{array}{c}\text { Yes } \\
(\mathrm{O}-\mathrm{E})^{2} / \mathrm{E}\end{array}$ & No \\
$(\mathrm{O}-\mathrm{E})^{2} / \mathrm{E}$ & \\
0.166667 & 0.666667 & \\
0.083333 & 0.083333 & ACCEPT \\
0.666667 & 0.166667 & \\
\hline \multicolumn{4}{c}{$\sum(\mathrm{O}-\mathrm{E})^{2} / \mathrm{E}=1.833333$} &
\end{tabular}

\subsection{Relative Importance of Different HR Functions}

Not all HR functions are of equally needed to be outsourced. Clearly, in a country like us activities like recruiting and selection require greater sophistication than the functions like temporary staffing, apparently, therefore of much greater relevance for outsourcing. The relative importance of various HR function was done by converting ordinal ratings of the functions to numeric interval value. It was determined using the following scale:

Then the numbers were averaged to find which function is more important to the organizations on average.

Result of the analysis:

Table 7 shows Relative importance of different HR functions. Figure 1 shows the histogram of ordinal response of relative importance of different HR functions. The analysis shows that Recruiting and Selection is ranked first according to the importance to the organization. Temporary staffing is considered to be of lowest importance among other HR functions by importance. The functions in order of importance are as follows:

1) Recruiting and Selection

2) Appraisal

3) Training and Development

4) Job Design

5) Compensation and Reward

6) Employee Benefits

7) Strategic HR planning

8) Employee Assistance /Counseling

9) Temporary Staffing

Table 7. Ordinal response of relative importance of different HR functions

\begin{tabular}{lc}
\hline Little & 1 \\
Much & 3 \\
Not so much & 2 \\
Very little & 0 \\
Very much & 4 \\
Little & 1 \\
Much & 3 \\
Not so much & 2 \\
Very little & 0 \\
Very much & 4 \\
\hline Ordinal response for importance of a function & 1 \\
Very little & 2 \\
Little & 3 \\
Not so much & 4 \\
Much & 5 \\
Very much & 4 \\
\hline
\end{tabular}




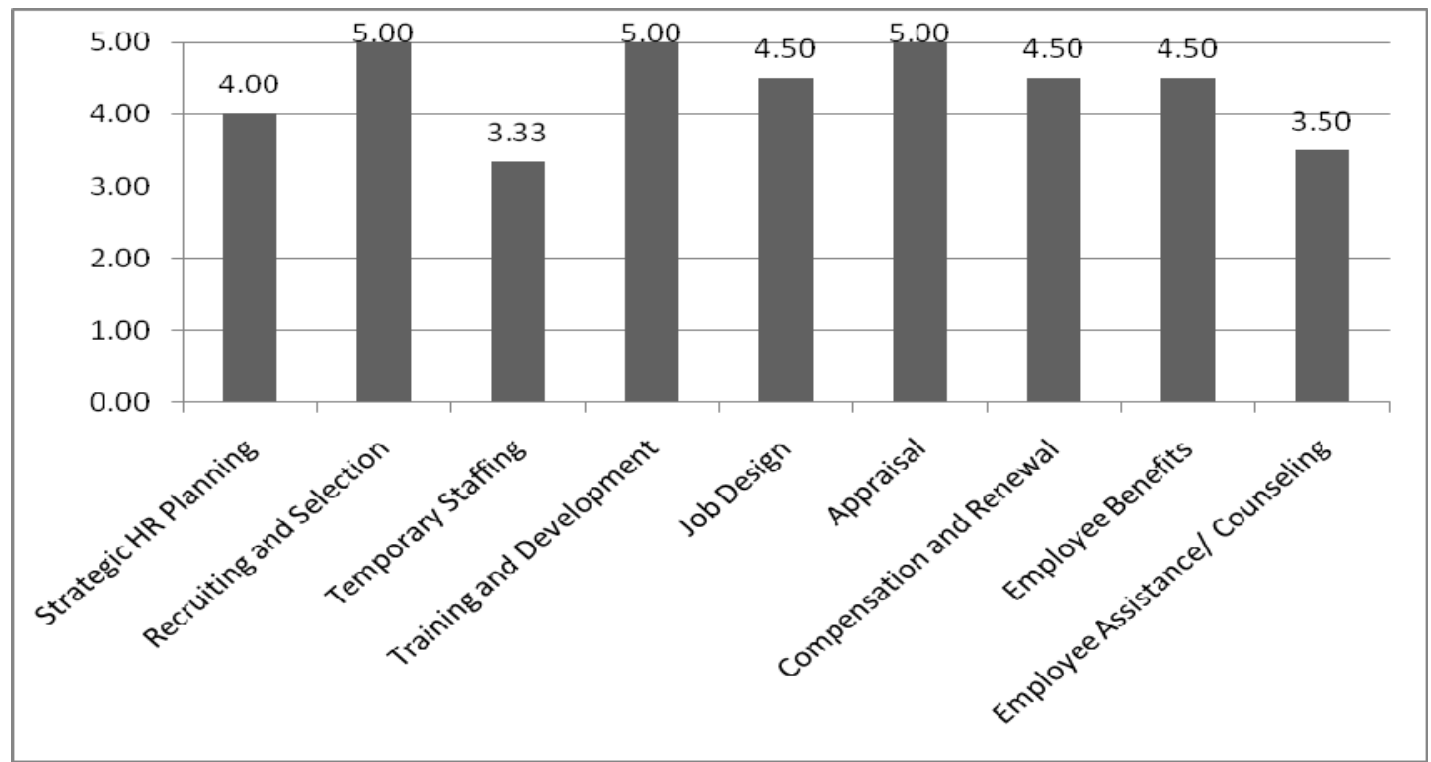

Figure 1. Histogram of Ordinal response of relative importance of different HR functions

\subsection{Causes of Outsourcing}

The causes for outsourcing can be anything between desires to save money to compensate for lack of experience in handling HR related affairs. The most prominent of the reasons include desire to achieving special competence, improvements in quality, save time, save money, and lack of experience. Besides, there was also an attempt to see whether these motives that usually prompt people to outsource vary according to different functions of an organization.

Method: Frequency analysis was done to identify the most frequent reason of outsourcing HR function.

Result of the analysis:

Table 8 and Figure 2 shows the causes of outsourcing. Among others, it was found that the most important cause of outsourcing HR function is the desire to special competence of the HR firms for $40 \%$ of the total, followed closely by improve quality and harnessing saving time, representing $25 \%$ and $20 \%$ respectively. Other significant causes of outsourcing include desire to save money and compensating for the lack of experience.

Table 8. Causes of outsourcing

\begin{tabular}{|c|c|c|c|c|c|c|c|c|c|c|}
\hline Functions & 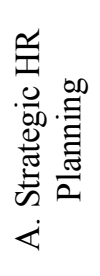 & 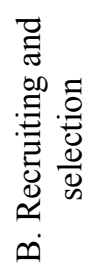 & 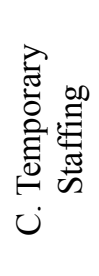 & 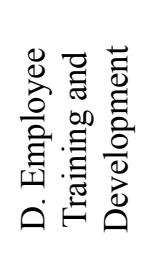 & 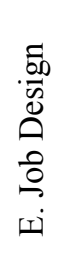 & 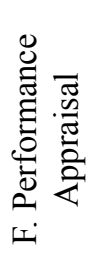 & 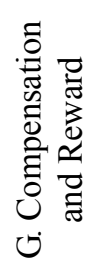 & 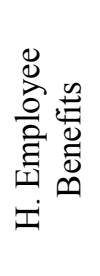 & 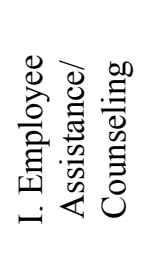 & 要 \\
\hline Save Money & & 1 & 1 & & & & & & & 2 \\
\hline $\begin{array}{l}\text { Improve } \\
\text { Quality }\end{array}$ & & & 1 & 3 & & & & & 1 & 5 \\
\hline $\begin{array}{c}\text { Special } \\
\text { Competence }\end{array}$ & 1 & 1 & 1 & 1 & 1 & 1 & 1 & 1 & & 8 \\
\hline Save Time & & 1 & 2 & & 1 & & & & & 4 \\
\hline $\begin{array}{l}\text { Lack of } \\
\text { Experience }\end{array}$ & & & 1 & & & & & & & 1 \\
\hline
\end{tabular}




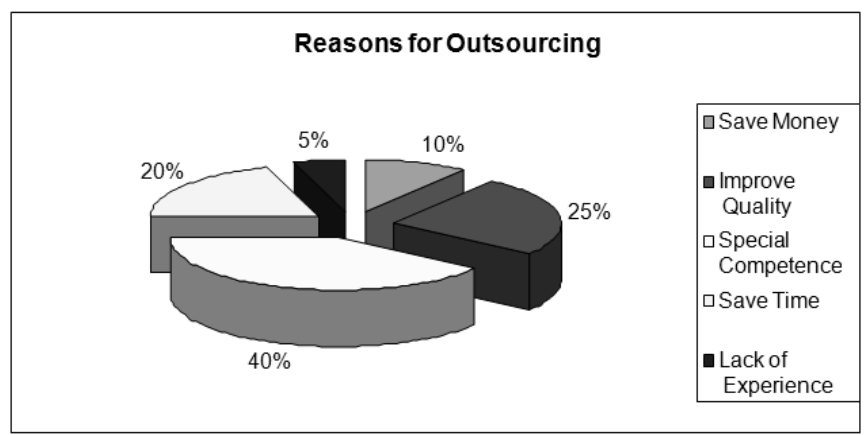

Figure 2. Pie-chart shows the reasons of outsourcing

\subsection{Causes of Not Outsourcing}

The possible reasons why HR activities are not outsourced are self sufficient HR departments, lack of availability of HR outsourcing activities, conflict with internal practices, dissatisfaction with the quality of the service rendered by the HR outsourcing companies, expense of the service and so forth. We attempted to discover the actual reasons that impede the firms from taking advantage of HR outsourcing.

Method of analysis: Again frequency for different reasons for different functions was counted.

Result of analysis:

Table 9 and Figure 3 show the causes of not outsourcing. The most frequent reason of not outsourcing HR functions, reportedly, is self sufficient HR department of the organizations; representing $56 \%$. The other significant reasons include services not available, conflict with internal practices, lack of satisfaction with the quality of service offered and cost of service, accounting for $23 \%, 9 \%, 6 \%$ and $6 \%$ respectively.

Table 9. Causes of not outsourcing

\begin{tabular}{|c|c|c|c|c|c|c|c|c|c|c|}
\hline & 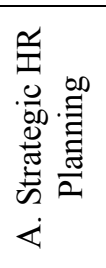 & 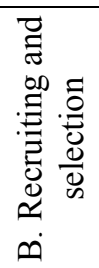 & 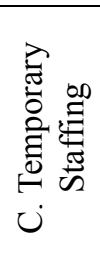 & 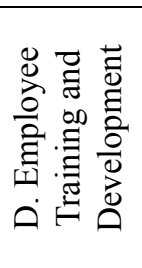 & 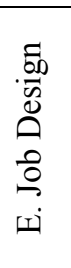 & 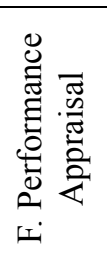 & 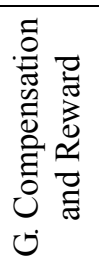 & 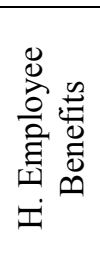 & 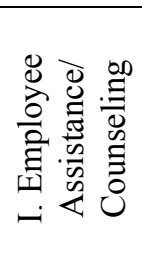 & 吾 \\
\hline Service not available & 1 & 1 & & & 2 & 1 & 1 & 1 & 1 & 8 \\
\hline $\begin{array}{l}\text { Quality of service not } \\
\text { satisfactory }\end{array}$ & & & 1 & 1 & & & & & & 2 \\
\hline Cost of service & & 1 & & 1 & & & & & & 2 \\
\hline $\begin{array}{l}\text { Self sufficient HR } \\
\text { department }\end{array}$ & 3 & 1 & 1 & 1 & 2 & 3 & 3 & 3 & 3 & 20 \\
\hline $\begin{array}{l}\text { Conflict with internal } \\
\text { practices }\end{array}$ & & & & & & & 1 & 1 & 1 & 3 \\
\hline
\end{tabular}

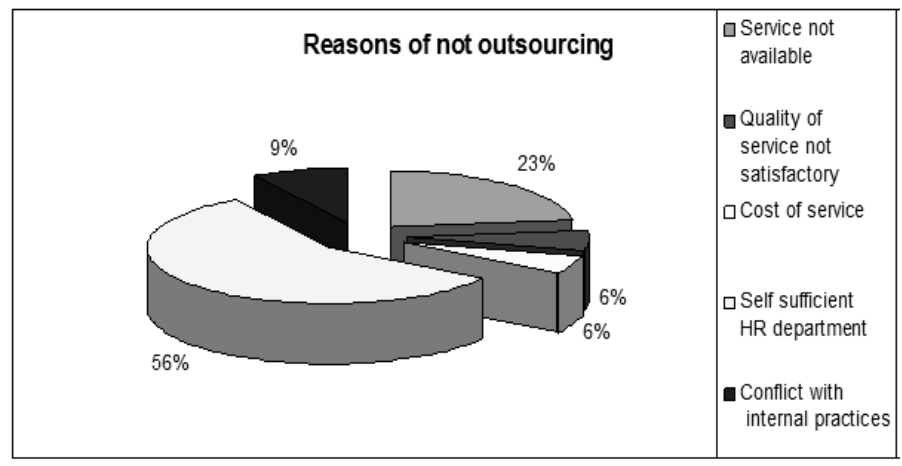

Figure 3. Pie-chart shows the reasons for not outsourcing 


\subsection{Satisfaction Level for the Results of Outsourcing}

The relative satisfaction level with the impact of outsourcing has on organizations and its operations generally differ in terms of bringing about a qualitative change in organizations activities to reduction in costs. To appraise the level of satisfaction various such issues were analyzed by converting ordinal responses to numeric value and averaging those values.

Result of analysis:

Figure 4 shows that, managers are very satisfied by the change in service quality that is brought in by outsourcing some HR functions. They are also satisfied with the impact of outsourcing on creating standardized practices. But they are not satisfied with ability to manage good outsourcing vendor relationship and organizations effectiveness in terms of human resource management.

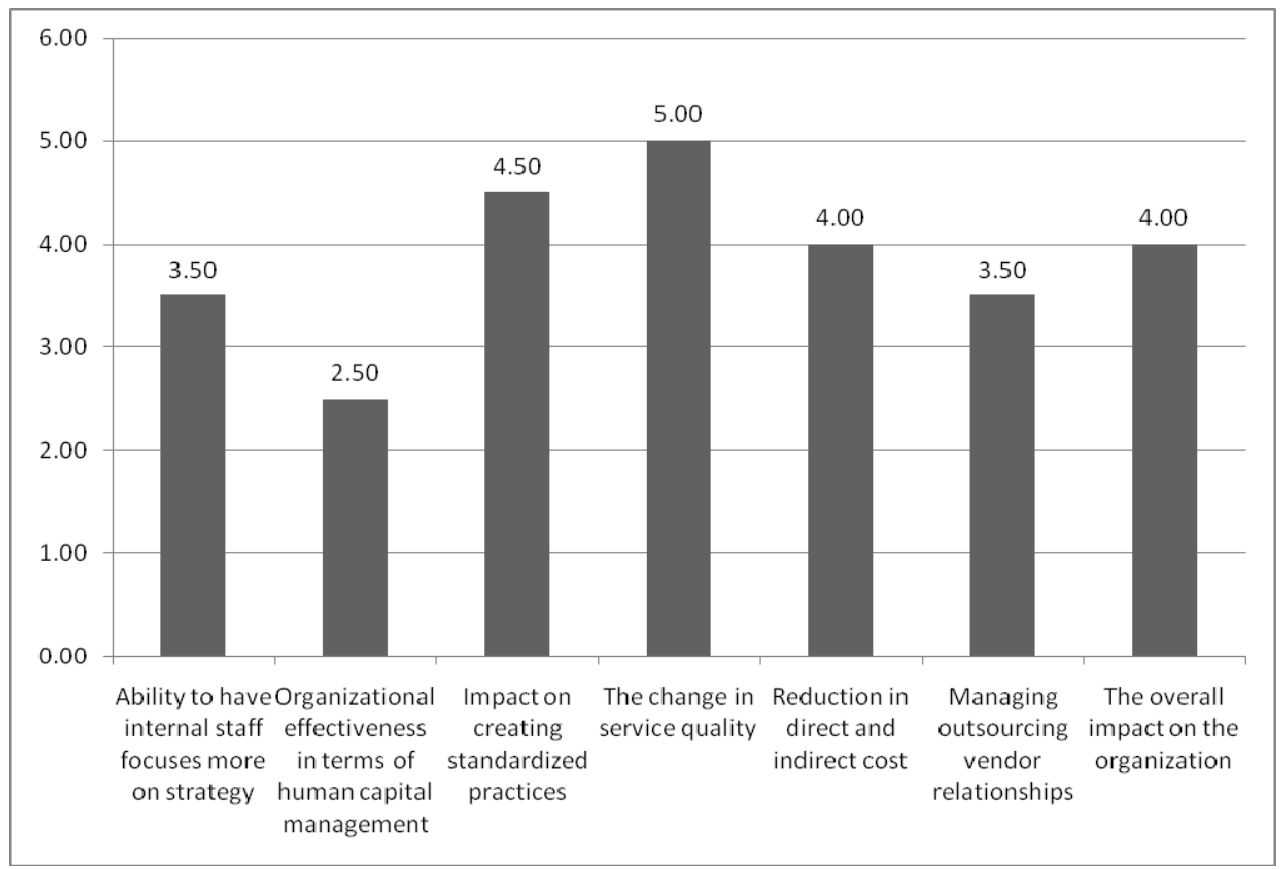

Figure 4. Histogram of satisfaction level for the results of outsourcing

\section{Conclusion}

Our analysis shows that Recruiting and Selection is ranked first according to the importance to the organization, followed by appraisal, strategic HR planning, and training and development. Temporary staffing is considered to be of lowest importance among other HR functions by importance.

On the other hand, it has been found that for such activities as training and development, employee appraisal and strategic HR planning outsourcing was the most frequent in contrast to the activities as job appraisal, compensation and rewards and employee benefits, where apparently employer confidence was the lowest.

The reasons for outsourcing HR functions included, primarily, improvement in quality, saving time and special competence in addition to the efforts to save money. In contrast, the most frequent reasons of not outsourcing HR functions are self sufficient HR department of the organizations, conflict with internal practices, and unsatisfactory quality of service and cost of service.

The result shows managers are very satisfied by the change in service quality that is brought in by outsourcing some HR functions. They are also satisfied in terms of the impact of outsourcing on creating standardized practices and cost reduction. However, they are not satisfied with ability to manage good outsourcing vendor relationship and organizations effectiveness in terms of human resource management.

\section{Policy Recommendations}

Searching through the industries and researching the findings we have concluded, within the boundary of our scope and facing all our limitations, and recommend the following for potential HR firm. 
1) The prospective firm should target the larger organizations in the field, as our finding affirms the fact.

2) Training \& Development as well as recruiting are amongst the most demanding services for the organizations studied. So, it is highly recommended to the prospective HR service provider to have strong hold in these services. And by establishing trust and reliability the firm can expand its service base to more confidential services, like Strategic HR planning.

3) Study shows that first three most important functions of organizations are Recruiting \& Selection, Appraisal, and Strategic HR planning. So, building expertise in those sectors would be more profitable for prospective HR firm.

4) The prospective firm should emphasize on improving quality of service, be highly efficient and have to control expenses in iron hand to give less expensive service to attain and continue with market share.

5) Conflict with internal practices is one of the most noted reasons why the organizations do not tend to outsource certain functions. This could be reduced by providing extensively tailored services to the organizations.

6) Organizations face difficulty in keeping relationship with HR service providers. So, this shall be a challenge for the prospective firm. The firm shall have to keep an eye on improving healthy relationship with its client.

\section{References}

Adler, P. S. (2003). Making the HR outsourcing decision. MIT Sloan Management Review. 45, 53-60.

Anderson, E., \& Weitz, B. A. (1986). Make -or- buy decisions: Vertical integration and marketing productivity. Sloan Management Review, 27, 3-20.

Barthelemy, J. (2003). The seven deadly sins of outsourcing. Academy of Management Executive. 17(2), 87-100. http://dx.doi.org/10.5465/AME.2003.10025203

Cook, M. F. (2001). Outsourcing Human resource function: strategies for providing enhance HR service at lower cost. New York: AMACOM

Dessler, G. (2003). Human Resource Management. India: Pearson Education Inc.

Gainey T. W., \& Klass, B. S. (2003). The outsourcing of training and development: factors impacting client satisfaction. Journal of Management, 29(2), 207-229. http://dx.doi.org/10.1177/014920630302900205

Gilley, K. M., Greer, C. R. \& Rasheed, A. A. (2004). Human Resource Outsourcing and performance in manufacturing firms. Journal of Business Research. 57, 232-240. http://dx.doi.org/10.1016/S0148-2963(02)00304-1

Greaver, M. F. II. (1999). Strategics Outsourcing: A structured approach to Outsourcing decision and initiatives. New York: AMACOM

Greer, C. R. (2001). Strategy and human resources: A general managerial approach (2nd ed.). Upper Saddle River (NJ): Prentic-Hall.

Greer, C. R., Youngblood, S. A., \& Gray, D. A. (1999). Human Resource Management Outsourcing: The make or buy decision. Academy of management Executive, 13, 85-96. http://dx.doi.org/10.5465/AME.1999.2210317

Gupta, U., \& Gupta, A. (1992). Outsourcing the IS function: Is it necessary for your organization? Information Systems Management, (Summer), 44-50. http://dx.doi.org/10.1080/10580539208906881

Harkins, P. J., Brown, S. M., \& Sullivan, R. (1995). Shining new light on a growing trend. HR Magazine, 20-25.

Kakabadse, A., \& Kakabadse, N. (2002). Trends in outsourcing. European Management Journal, 20, 189-198. http://dx.doi.org/10.1016/S0263-2373(02)00029-4

Klass, B. S. (2003). Professional employer organizations and their role in small and medium enterprise: the impact of HR outsourcing. Entrepreneurship theory and Practise, 28, 43-61.

Klass, B. S., McClendon, J., \& Gainey, T. W. (1999). HR outsourcing and its impact: The role of transaction costs. Personnel Psychology, 52, 113-136. http://dx.doi.org/10.1111/j.1744-6570.1999.tb01816.x

Klass, B. S., McClendon, J., \& Gainey, T. W. (2001). Outsourcing HR: The impact of organizational characteristics. Human Resource management. 40, 125-138. http://dx.doi.org/10.1002/hrm.1003

Lever, S. (1997). An analysis of marginal motivations behind outsourcing practicees in human resource. Human resource Planning, 20(2), 37-47. 
Leiblein, M. J., Reuer, J. J., \& Dalsace, F. (2002). DO make or buy decisions matter? The influence of Organizational governance on technological performance. Strategic management Journal, 23, 817-833. http://dx.doi.org/10.1002/smj.259

Milgate, M. (2001). Alliances, outsourcing and the learning organization. Westport, CN:Quorum.

Noe, R. A. (1997). Human Resource management: Gaining a Competitive Management (2th ed.). USA: The McGraw-Hill Companies Inc.

Vining, A., \& Globeman, S. (1999). A conceptual framework for understanding the outsourcing decision. European Management Journal, 17(6), 645-654. http://dx.doi.org/10.1016/S0263-2373(99)00055-9 